\title{
Large-Magnitude Miocene Extension in the Central Mojave Desert: Implications for Paleozoic to Tertiary Paleogeography and Tectonics
}

\author{
J. Douglas WaLKer
}

Department of Geology, University of Kansas, Lawrence

JOHN M. BARTLEY

Department of Geology and Geophysics, University of Utah, Salt Lake City

ALLEN F. GLAZNER

Department of Geology, University of North Carolina, Chapel Hill

\begin{abstract}
The main Cenozoic extensional structure in the central Mojave Desert is the Waterman Hills detachment fault, which places brittlely deformed synorogenic Miocene rocks on ductilely and cataclastically deformed footwall rocks. New data are presented regarding the timing, distribution, magnitude, and significance of early Miocene extension in the area. The mylonitic fabric in the lower plate was formed at $23 \mathrm{Ma}$, based on a zircon $\mathrm{U} / \mathrm{Pb}$ age from a synmylonitic intrusion. Upper plate strata consist of rhyolite flows overlain by sedimentary rocks that were apparently deposited during extensional faulting. These strata were tilted, folded, and intruded by synkinematic rhyolite plugs that are cut off at the detachment fault. Potassium metasomatism of the rhyolitic rocks is pervasive. Upper plate detrital sediment was derived from the rhyolitic rocks and from metamorphic and plutonic basement rocks not present in the area. The probable source of the exotic basement clasts is the Alvord Mountain area, presently located $35 \mathrm{~km}$ east-northeast of the Waterman Hills area. This source was probably much nearer to the Waterman Hills during deposition of the synorogenic deposits and has been subsequently shifted by extensional deformation. Distinctive Mesozoic plutonic rocks provide a possible tie between upper and lower plate rocks. Similar poikilitic gabbro bodies in the Goldstone area and the Iron Mountains suggest slip on the Waterman Hills detachment fault to be about $40-50 \mathrm{~km}$. This is also consistent with other offset markers, such as the western edge of a Mesozoic dike swarm. When 15-20 $\mathrm{km}(?)$ of Tertiary extension is restored, Paleozoic eugeoclinal rocks are placed structurally above their miogeoclinal counterparts. Combined with the distribution of Triassic and Jurassic rocks, this implies post-Early Triassic and pre-Late Jurassic stacking of these lithologies.
\end{abstract}

\section{INTRODUCTION}

Evidence for significant Tertiary crustal extension in the central Mojave Desert has been recognized for several years [Dokka and Glazner, 1982; Dokka, 1986, 1989; Dokka and Woodburne, 1986; Dokka et al., 1988; Glazner et al., 1988a, b, 1989]. Recent work has shown that the Waterman Hills, Hinkley Hills, and Mitchel Range (Figures 1, 2, and 3) constitute a Cordilleran-type metamorphic core complex [e.g., Davis and Coney, 1979; Davis and Lister, 1988]. A low-angle normal fault, the Waterman Hills detachment fault (WHDF), is exposed in the Waterman Hills and Mitchel Range (Figure 2) where it places brittlely deformed, tilted Tertiary sedimentary and volcanic hanging-wall rocks on a footwall of granitoid and metamorphic rocks. There is a complete lithologic mismatch between footwall and hanging-wall rocks. Footwall rocks record ductile shear which intensifies structurally upward toward the WHDF. Near the detachment, the ductile fabric is overprinted by cataclasis and chloritic alteration [Bartley and Glazner, 1987, Bartley et al., 1989]. Hanging-wall rocks show in-

Copyright 1990 by the American Geophysical Union. tense potassium metasomatism. Each of these features is widely recognized as typical of areas of intense Cenozoic extension in the metamorphic core complexes of the southwestern Cordillera.

The magnitude and distribution of Cenozoic deformation in the Mojave Desert are critical to unraveling the pre-Tertiary tectonics of the region. Mesozoic or late Paleozoic deformation caused rocks of the Cordilleran eugeocline and miogeocline to occur in anomalously close proximity in the central Mojave (Figure 3) [Burchfiel and Davis, 1981]. Eugeoclinal strata crop out in the Lane Mountain and Goldstone areas [McCulloh, 1952; Miller and Sutter, 1982], and probable miogeoclinal rocks are exposed in the Hinkley Hills, Waterman Hills, and Mitchel Range [Kiser, 1981; Glazner et al., 1988a]. Juxtaposition of eugeoclinal and miogeoclinal facies probably occurred by strike-slip faulting of Pennsylvanian and Permian age [Walker, 1985, 1988]. Presently, this boundary makes a pronounced westward bend in the central Mojave Desert (Figure 1). Walker [1988] showed that restoration of Tertiary extensional and strike-slip faulting may eliminate most of this bend, but his reconstruction was based on poorly constrained estimates of the magnitude and position of extensional faults. In addition, major Mesozoic tectonic boundaries have been proposed to pass through the Mojave Desert [e.g., Silver and 


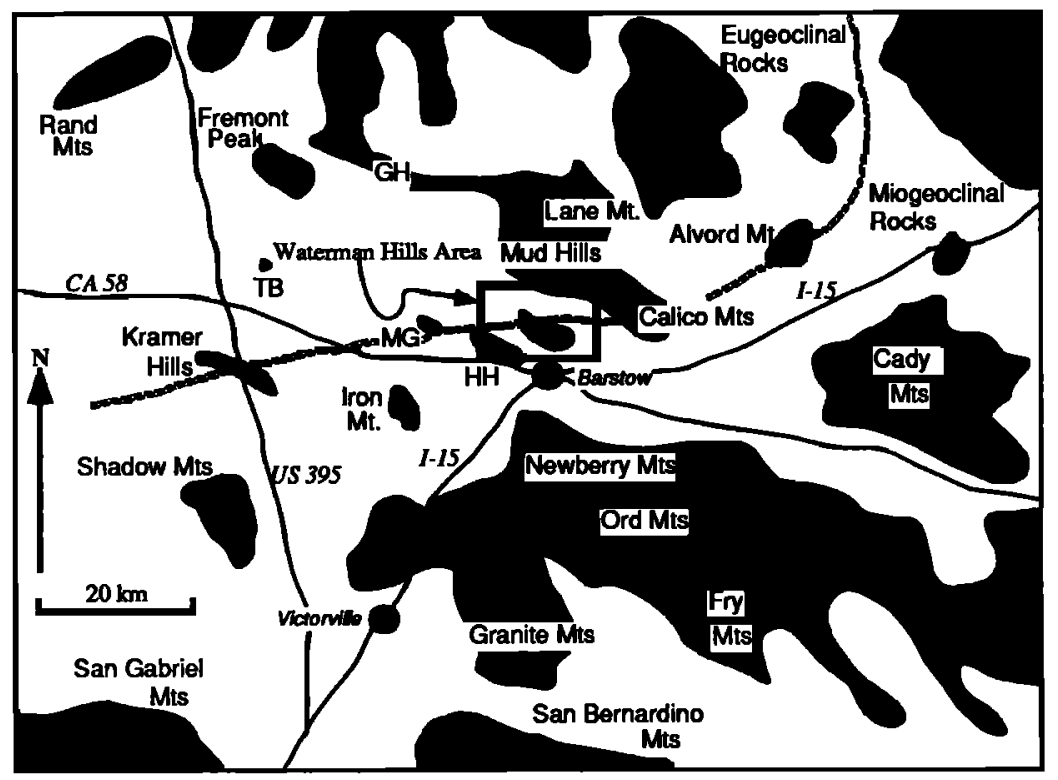

Fig. 1. Regional location map of the central Mojave Desert. Ranges are shown in black, modern valleys and basins in white. GH, Gravel Hills; MG, Mount General; HH, Hinkley Hills; TB, The Buttes. Approximate boundary between eugeoclinal and miogeoclinal rocks shown as heavy line.

Anderson, 1974; Lahren and Schweickert, 1989], but these inferences have not been adequately tested against actual evidence for Mesozoic deformation in the Mojave area. This is partly because Cenozoic extension needs to be assessed first.

In this paper we present new data regarding the geological relations between upper and lower plates of the WHDF and the age of lower plate deformation. We report new data concerning contact relations and provenance of syntectonic sedimentary strata and a possible match between hanging-wall and footwall rocks that supplies a semiquantitative estimate of displacement. These data form the basis of an improved model for the magnitude, the kinematics, and the timing of Tertiary extension, which can then be used to refine reconstructions of pre-Tertiary paleogeography and tectonics.

\section{Lower Plate Relations}

The lower plate of the WHDF is well exposed in the Waterman Hills and Mitchel Range where it consists of Waterman Gneiss intruded by hornblende-biotite granodiorite (Figure 2). The name Waterman Gneiss has been applied to a varied collection of metasedimentary and metaigneous rocks exposed in the central Mojave Desert [Bowen, 1954; Dibblee, 1968, 1970]. The metasedimentary portion of the gneiss consists of upper Precambrian and Paleozoic miogeoclinal facies rocks (Kiser [1981], and our reconnaissance). The igneous portion, although largely mapped as Precambrian [Jennings, 1977], apparently consists largely of Mesozoic plutonic rocks [Glazner et al., 1988b]. It is presently unclear how much, if any, of the gneiss complex is composed of Precambrian plutonic and metamorphic rocks or possibly eugeoclinal rocks. Regional isotopic data on Mesozoic plutonic rocks suggest, however, that Precambrian rocks are present at depth [Kistler and Peterman, 1978], as does an inherited component in zircons from a Miocene intrusion in the Mitchel Range (see below). The age of the hornblende-biotite granodiorite that intrudes the Waterman Gneiss is not known, but it is probably Jurassic or Cretaceous based on the presumed ages of similar plutons in the region [Burchfiel and Davis, 1981; Miller and Sutter, 1982]. Field relations and mineral assemblages show that the Waterman Gneiss was deformed and metamorphosed at amphibolite grade prior to intrusion of the granodiorite [Kiser, 1981; Glazner et al., 1988a]. The prechlorite-grade mineral assemblage exists only in porphyroclasts at present and not as a single distinct fabric.

A chlorite-grade mylonitic fabric that defines a northeast trending lineation is developed in both the Waterman Gneiss and the granodiorite [Bartley and Glazner, 1987]. Kinematic indicators record a top-tonortheast sense of shear [Dokka and Woodbume, 1986; Glazner et al., 1988a; Dokka et al., 1988; Dokka, 1989]. In the Waterman Gneiss this mylonitic fabric overprints the (Mesozoic?) amphibolite-facies metamorphism. We have not yet studied the relations of the two metamorphic events in the Waterman Gneiss in sufficient detail to resolve a spatial pattern in this overprinting, if any is present. However, only the mylonitic fabric is present in the granodiorite. This fabric systematically intensifies structurally upward toward the WHDF.

Intense cataclasis overprints the mylonitic fabric within a few meters of the detachment. Commonly associated with the cataclasis are pervasive chloritic alteration and replacement deposits of fine-grained blue tourmaline [Kramer and Allen, 1954]. Similar cata- 


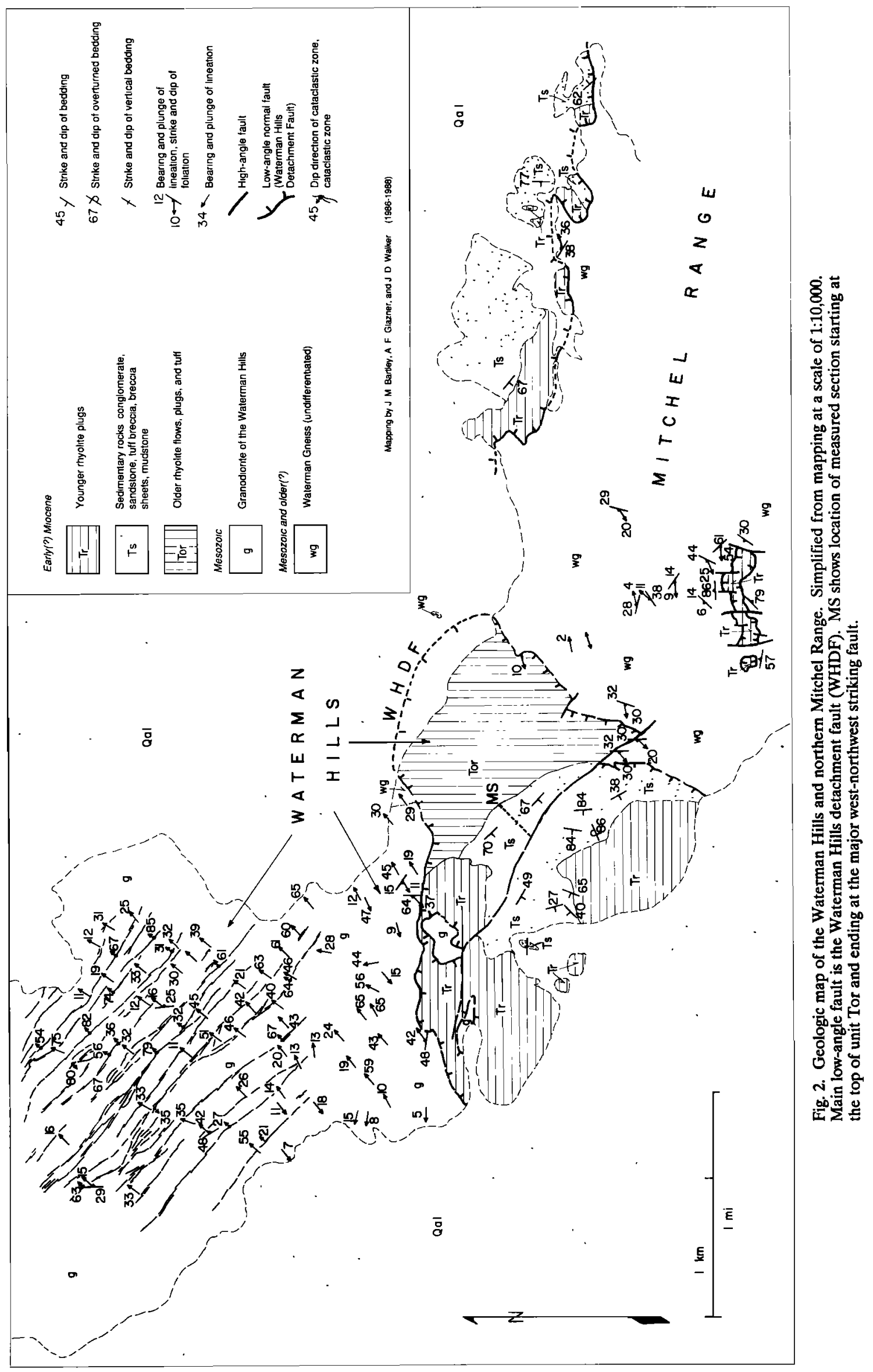




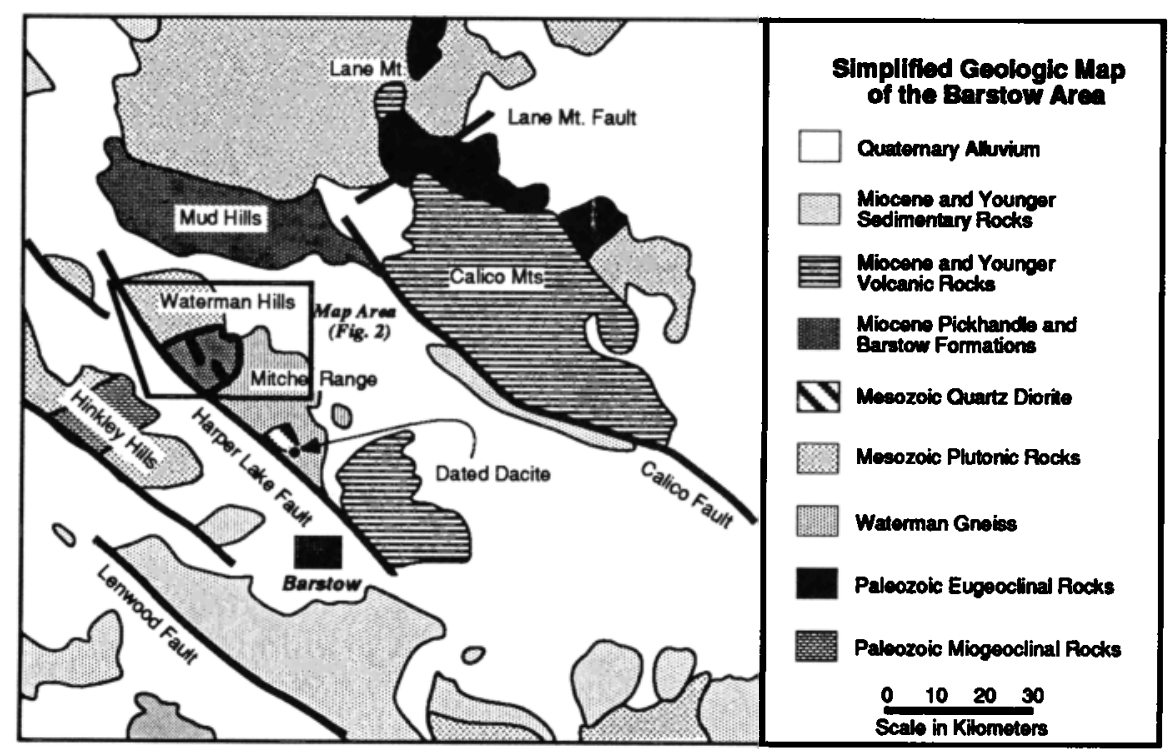

Fig. 3. Detailed location map of the Barstow area. Position of major faults are shown, as well as the limits of eugeoclinal and miogeoclinal rocks.

clasites also occur in numerous zones that cut downward into the lower plate (Figure 2). These zones dip steeply to the NE (mean about $75^{\circ}$ ) and contain mainly downdip striae. We interpret these to record a late phase of layer-parallel shortening [Bartley et al., 1989].

Based on these field relations and new age data presented below, we interpret the mylonitization to be related to early Miocene movement on the WHDF. However, the mylonitic fabric commonly is somewhat discordant to the WHDF, especially along its northern trace, and in places is sharply truncated (Figure 2) [also see Glazner et al., 1988a, Figure 16]. This relation is reminiscent of the structural relations along the Whipple Mountains metamorphic core complex, where the lower plate mylonitic fabric is truncated by a Miocene extensional detachment [Davis et al., 1980; Davis and Lister, 1988]. The possibility that the mylonitic fabric is older than and unrelated to the Tertiary fault thus must be addressed. We have identified a porphyritic dacite intrusion in the Mitchel Range (Figure 3; south of the map area of Figure 2) that cuts mylonitic fabric in the Waterman Gneiss, but itself contains mylonite zones. The mylonite zones in the dacite exhibit a top-tonortheast fabric identical to that in the granodiorite

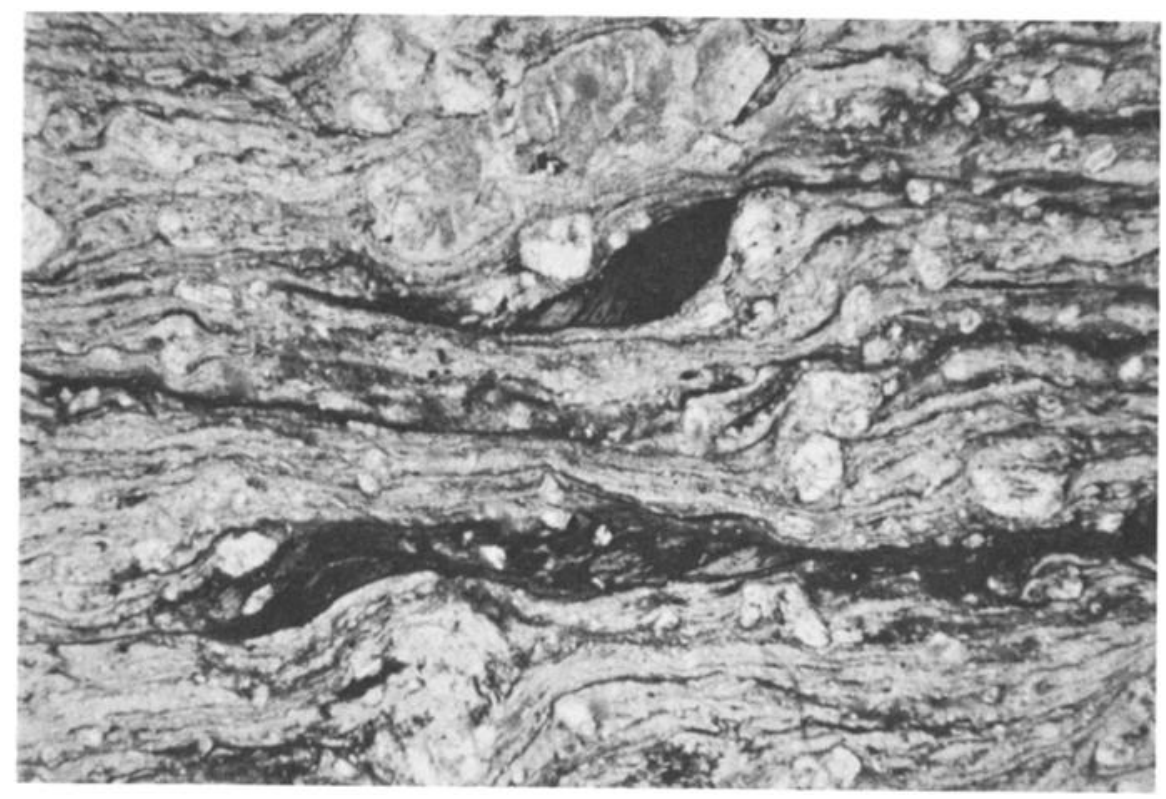

Fig. 4. Photomicrograph of ductilely sheared dacite porphyry from the synkinematic intrusion in the Mitchel Range, viewed in plane-polarized light. This oriented sample was collected a few meters from the U/Pb zircon sample. The thin section was cut parallel to lineation and perpendicular to foliation, in a plane roughly vertical and northeast striking, and is viewed toward the northwest. Dextral shear sense, indicated by asymmetry of biotite "fish" (dark grains), indicates top-tonortheast shear, consistent with kinematic indicators in other mylonitic rocks in the Waterman Hills and Mitchel Range [Glazner et al., 1988a; Dokka et al., 1988]. 


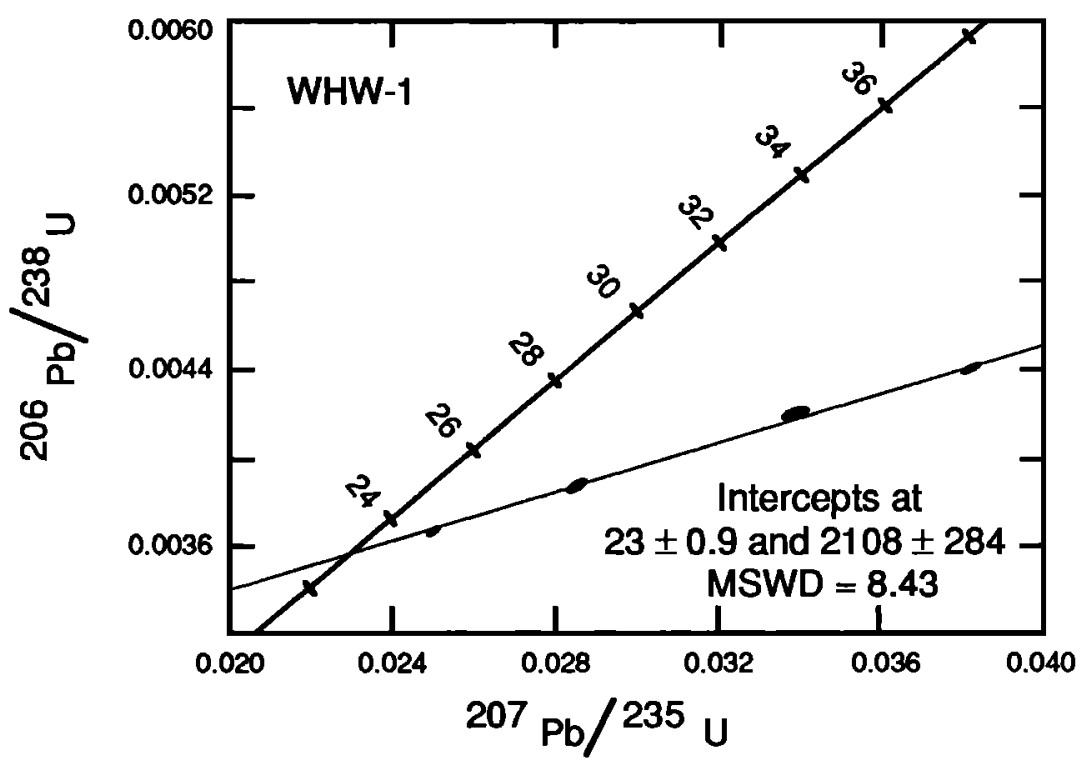

Fig. 5. Concordia plot for dacite intrusion. Results are plotted using regression model 2 of Ludwig [1983]. Data are shown by error ellipses representing 2 -sigma uncertainty.

beneath the WHDF (Figure 4); therefore the dacite intrusion probably was intruded during mylonitization. The following section presents geochronological results from this intrusion.

Zircons from the dacite intrusion were analyzed by the U-Pb method. Results are given in Table 1 and Figure 5. The lower intercept age of this rock is $23 \pm$ $0.9 \mathrm{Ma}$ and the upper is about $2100 \mathrm{Ma}$ (Figure 5 and Table 1). We interpret the lower intercept to be the age of crystallization. Recent lead loss is not displayed in the systematics of this sample. Such loss is unlikely because (1) the intrusion was probably cool by $18 \mathrm{Ma}$, when deposition of the posttectonic Barstow Formation began [McFadden et al., 1988]; (2) the Mitchel Range had apparently cooled below $70^{\circ} \mathrm{C}$ by $19 \mathrm{Ma}$ [Dokka and Baksi, 1988; Dokka, 1989, p. 367]; and (3) there is no evidence in thin section or hand sample for extensive weathering or hydrothermal alteration. The upper intercept age is reasonable considering similar results of Wooden et al. [1988], and 2.0-2.3 Ga Nd model ages for this region [Bennett and DePaolo, 1987].

The $23 \mathrm{Ma}$ age for intrusion and ductile deformation is broadly similar to ages of volcanic rocks in the Whipple Mountains area. Davis and Lister [1988, p. 144145] interpret lower plate mylonitization to have been active during Oligo-Miocene time and to have ceased by $21.5 \mathrm{Ma}$. The similarity of ages suggests that magmatism and ductile extension in the central Mojave Desert

TABLE 1. Analytic Data for Synmylonitic Dacite

\begin{tabular}{|c|c|c|c|c|c|c|c|c|c|c|c|c|}
\hline \multirow[b]{2}{*}{ Fraction } & \multirow[b]{2}{*}{$\begin{array}{c}\text { Sample } \\
\text { Weight, mg }\end{array}$} & \multirow[b]{2}{*}{ U. ppm } & \multirow[b]{2}{*}{${ }^{206} \mathrm{~Pb}^{*}$, ppm } & \multicolumn{3}{|c|}{ Measured Ratios } & \multicolumn{3}{|c|}{ Radiogenic Ratios } & \multicolumn{3}{|c|}{ Ages, Ma } \\
\hline & & & & $\begin{array}{l}{ }^{206} \mathrm{~Pb} / \\
{ }^{204} \mathrm{~Pb}\end{array}$ & $\begin{array}{r}{ }^{207} \mathrm{~Pb} / \\
206 \mathrm{~Pb}\end{array}$ & $\begin{array}{r}{ }^{208} \mathrm{~Pb} / \\
{ }^{206} \mathrm{~Pb}\end{array}$ & $\begin{array}{r}{ }^{206} \mathrm{~Pb}^{* /} \\
238 \mathrm{U}\end{array}$ & $\begin{array}{r}{ }^{207} \mathrm{~Pb}^{* /} \\
235_{\mathrm{U}}\end{array}$ & $\begin{array}{c}{ }^{207} \mathrm{~Pb}^{* /} \\
206 \mathrm{~Pb}^{*}\end{array}$ & $\begin{array}{r}206 \mathrm{~Pb}^{* /} / \\
238 \mathrm{U}\end{array}$ & $\begin{array}{r}{ }^{207} \mathrm{~Pb}^{* /} / \\
235 \\
{ }^{\mathrm{U}}\end{array}$ & $\begin{array}{r}207 \mathrm{~Pb} * / \\
206 \mathrm{~Pb} *\end{array}$ \\
\hline $\begin{array}{l}\mathrm{nm}(0)<200 \\
\mathrm{~nm}(1)<200 \\
\mathrm{~nm}(2)<200 \\
\mathrm{~nm}(3)<200\end{array}$ & $\begin{array}{l}1.574 \\
2.386 \\
1.140 \\
2.019\end{array}$ & $\begin{array}{r}1604.4 \\
628.7 \\
815.9 \\
588.3\end{array}$ & $\begin{array}{l}5.893 \\
1.993 \\
3.145 \\
2.035\end{array}$ & $\begin{array}{r}828.2 \\
1299.4 \\
583.2 \\
405.1\end{array}$ & $\begin{array}{l}0.07611 \\
0.06059 \\
0.08775 \\
0.08931\end{array}$ & $\begin{array}{l}0.1537 \\
0.1141 \\
0.1646 \\
0.1982\end{array}$ & $\begin{array}{l}0.00420 \\
0.00367 \\
0.00439 \\
0.00388\end{array}$ & $\begin{array}{l}0.03389 \\
0.02494 \\
0.03816 \\
0.02850\end{array}$ & $\begin{array}{l}0.058584 \\
0.049277 \\
0.062998 \\
0.053240\end{array}$ & $\begin{array}{l}27.0 \\
23.6 \\
28.3 \\
25.0\end{array}$ & $\begin{array}{l}33.8 \\
25.0 \\
38.0 \\
28.5\end{array}$ & $\begin{array}{ll}551.6 & (12) \\
161.0 & (6) \\
708.2 & (7) \\
339.4 & (10)\end{array}$ \\
\hline
\end{tabular}

(12) analytical error on age in m.y. (2-sigma). nm(\#) nonmagnetic on Frantz separator at angle of tilt \# degrees. $<200$ size in standard mesh. Zircon disolution followed the methods of Krogh [1973] and Parrish [1987]. Elemental separation was done with HBr anion column chemistry for lead and HCl column chemistry for uranium. Samples were abraded following the methods of $K r o g h$ [1982]. Decay constants used were ${ }^{238} \mathrm{U}_{=0.15513 \times 10^{-9}} \mathrm{yr}^{-1}$ and ${ }^{235} \mathrm{U}=0.98485 \times 10^{-9} \mathrm{yr}^{-1}$ [Steiger and Jager, 1977]. Isotopic analyses were determined on a VG Sector multicollector thermal ionization mass spectrometer. A mass fractionation correction of $0.10 \% / a m u$, as determined by standard runs on NBS 981 (common lead) and NBS 982 (equal atom lead), was applied to the lead data. Errors on ${ }^{206} \mathrm{~Pb} / 204 \mathrm{~Pb}$ were minimized by use of a Daly multiplier. All analyses were carried out during 1988 and 1989 when laboratory blank averaged $0.12 \mathrm{ng}$ total lead and $0.2 \mathrm{ng}$ uranium. Errors on data were computed using data reduction program of Ludwig [1983]. Common lead corrections were made using values determined from Stacey and Kramers [1975] for the lower intercept age. Values used are ${ }^{206} \mathrm{~Pb} / 204 \mathrm{~Pb}=18.688$, ${ }^{207} \mathrm{~Pb} / 204 \mathrm{~Pb}=15.627$, and ${ }^{208} \mathrm{~Pb} /{ }^{004} \mathrm{~Pb}=38.589$. Sample taken from dike that intrudes unit qd of Dibblee [1970]. Location of sample is $34^{\circ} 55^{\prime} 7.7^{\prime \prime} \mathrm{N}$, $116^{\circ} 59^{\prime} 18.8^{\prime \prime}$ W. Detailed field relations of this body are described by J. M. Bartley et al./ [1989].

radiogenic component. 
were roughly coeval with similar events in the Colorado River area. [cf. Hileman et al., this issue].

\section{UPPER PLATE RELATIONS}

The upper plate of the WHDF in the Waterman Hills and Mitchel Range consists of deformed and altered Tertiary igneous and sedimentary rocks. A partial stratigraphic section for Tertiary rocks of the Waterman Hills is presented in Figure 6 (location of section in Figure 2). This section is schematic and generalized because of the complex structure in the area and intricate lateral changes in the stratigraphy. This

Stratigraphic Section - Waterman Hills

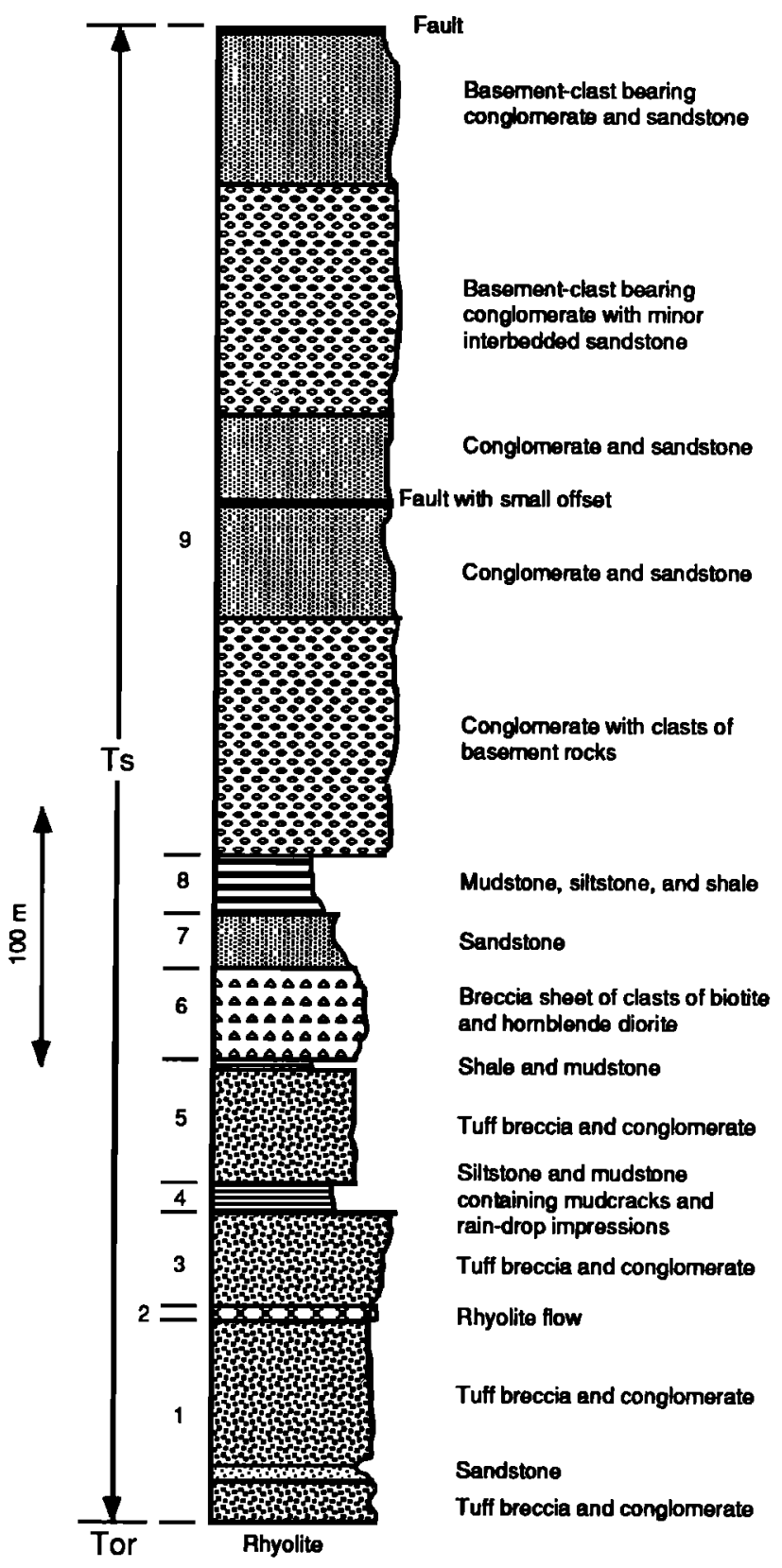

Fig. 6. Upper plate Miocene stratigraphy, unit Ts of Figure 2, in the Waterman Hills.

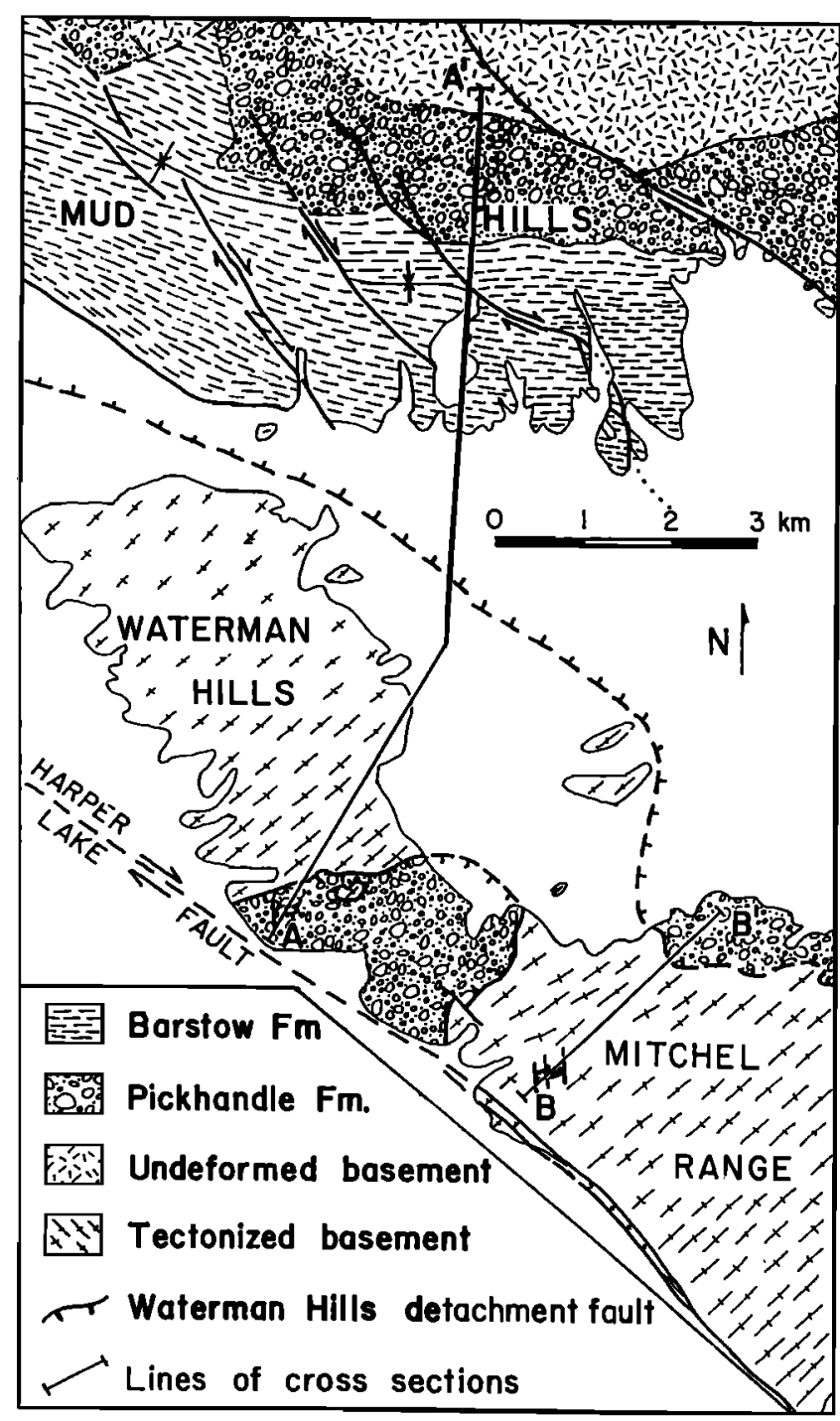

Fig. 7. Tectonic map showing inferred relations between the Waterman Hills-Mitchel Range core complex and the Mud Hills. Tectonic fabric in the Waterman Hills is interpreted to be Tertiary in age; it is probably composite Tertiary/Mesozoic in the Mitchel Range. Geology of the Mud Hills is simplified from Dibblee [1968]. Note lines of cross sections in Figure 8.

sedimentary sequence is cut and deformed by discordant rhyolitic plugs (unit Tr, Figure 2), which are in turn cut by the WHDF. Correlative strata exposed to the north in the Mud Hills, assigned to the Pickhandle Formation by Dibblee [1968], were deposited on undeformed Mesozoic intrusive rocks which we interpret to represent upper plate basement rocks (Figure 7; see below). The following discussion focuses on the stratigraphy and structure of syntectonic upper plate strata in the Waterman Hills, Mitchel Range, and Mud Hills (Figures 2,6 , and 7).

\section{Stratigraphy}

The Tertiary section in the Waterman Hills and Mitchel Range is everywhere in fault contact (along the WHDF) with the pre-Tertiary basement and Tertiary 
intrusions. The stratigraphically lowest preserved part of the section in the Waterman Hills consists of rhyolite flows and tuffs (unit Tor, Figures 2 and 6). Alteration of the rhyolite is pervasive. Plagioclase has been completely replaced by adularia, and secondary chalcedony and calcite are abundant. The rhyolites, which comprise both flows and flow breccias, are brecciated and fragmental near their tops.

The rhyolite sequence is overlain by a heterogeneous assemblage of tuff, tuff breccia, conglomerate, sandstone, mudstone, and monolithologic and polymict breccia sheets of pre-Tertiary basement lithologies (unit Ts, Figures 2 and 6). The basal part of this assemblage consists of $85 \mathrm{~m}$ of light green to light red weathering tuff breccia and conglomerate derived from the underlying rhyolite (subunit 1 ). The tuff breccia consists of massive to faintly bedded tuffaceous sandstone and siltstone with isolated pebble- to boulder-sized clasts of rhyolite deposited by tuffaceous mudflows or debris flows. Individual units are up to $20 \mathrm{~m}$ thick. Intercalated maroon-weathering conglomerate occurs in thin to thick $(9 \mathrm{~m})$ beds that range from well sorted to poorly sorted. Stratification is defined by alternating layers of clast-rich and clast-poor sandstone and conglomerate, although the unit is locally massive. This interval of tuff breccia and conglomerate is capped by a 3 - $\mathrm{m}$-thick brecciated rhyolite flow (subunit 2) that resembles the stratigraphically lower rhyolite. The rhyolite flow is overlain by another $\mathbf{3 8} \mathbf{m}$ of conglomerate and tuff breccia (subunit 3), that is similar to, but typically better sorted and stratified than, the unit below. Stratified sandstone is common above the lowest $5 \mathrm{~m}$. These three subunits were probably deposited in a fluvial setting with locally abundant debris flows.

Passing up section, the generally coarse character of the Tertiary rocks is interrupted by $11 \mathrm{~m}$ of siltstone, mudstone, and shale (subunit 4). These rocks weather red to green and contain laminae $0.5-3 \mathrm{~cm}$ thick. Although the rocks are altered to jasperoid, rain drop impressions and mud cracks are clearly discernible. These rocks probably originated in an ephemeral pond or playa. This unit is overlain by about $45 \mathrm{~m}$ of tuff breccia and conglomerate, that are in turn overlain by 1 $m$ of shale and mudstone (subunit 5).

The next higher unit is a 35-m-thick breccia sheet derived from biotite diorite and hornblende diorite, containing clasts from 0.1 to $2 \mathrm{~m}$ in diameter (subunit 6). This and similar units upsection probably represent landslide or debris flow deposits. This unit is overlain by $20 \mathrm{~m}$ of rhyolitic sandstone (subunit 7), followed by $23 \mathrm{~m}$ of mudstone, siltstone, and shale (subunit 8) that resemble the strata that underlie the diorite breccia sheet.

The remainder of the exposed stratified sequence consists of $330 \mathrm{~m}$ of conglomerate and sandstone intercalated with sheets of brecciated basement rocks (subunit 9). Although tuff breccia layers persist into this part of the section, conglomerate with both volcanic and basement clasts predominates. The conglomerate varies from poorly to well bedded but, in general, is better stratified than units below. In addition, local cut and fill structures and cross stratification are present. The sedimentary features record deposition in a fluvial setting, possibly near the center or toe of an alluvial fan. The section probably continues further, but measurement was stopped at a large fault that appears to repeat section in the core of the large syncline (Figure 2). Further measurement was impossible because lateral facies changes in these rocks prevent a unique offset of the section.

The sedimentary rocks are intruded by rhyolite plugs (unit Tr, Figure 2). These plugs are porphyriticaphanitic with phenocrysts of quartz, plagioclase, and biotite. Phenocrysts are about $1 \mathrm{~mm}$ in diameter. The texture and mineralogy of these rocks has been severely overprinted by K-metasomatism.

In summary, the upper plate sedimentary sequence (Ts) is composed predominantly of rhyolitic volcanic and coarse clastic rocks, with subordinate fine-grained clastic intervals. Provenance changes upsection from a volcanogenic, probably local source to more diverse sources that include a major component of pre-Tertiary basement rocks. These relations are consistent with the hypothesis that this sequence was deposited during extensional faulting accompanied by volcanic outbursts in a normal fault bounded basin. Faulting created the topographic relief necessary to unroof the basement rocks and to shed coarse debris flows.

\section{Regional Correlation and Source Areas}

Miocene rocks in the Waterman Hills correlate with the Pickhandle Formation of $\mathrm{McCulloh}$ [1952] and Dibblee $[1968,1970]$ and probably with the Spanish Canyon Formation and possibly the Clews Fanglomerate at Alvord Mountain [Byers, 1960; Dokka et al., 1988]. Strata of the Pickhandle Formation in the Mud Hills, directly west on strike from the type area in Pickhandle Pass [McCulloh, 1952], are strikingly similar to the upper plate sedimentary section (Ts) in the Waterman Hills, including the distinctive basement-clast conglomerate and breccia sheets (Dibblee [1968] and our reconnaissance). However, the Pickhandle Formation in the Mud Hills is free of the effects of K-metasomatism and is in stratigraphic contact with untectonized quartz monzonite [Dibblee, 1968]. These relations indicate that both the Pickhandle Formation and the subjacent preTertiary rocks in the Mud Hills belong to the upper plate of the WHDF.

The Pickhandle Formation in the Mud Hills is overlain unconformably by the Barstow Formation [Dibblee, 1968]. We interpret the Barstow Formation to encompass postkinematic fluvio-lacustrine rocks deposited in an extensional basin formed during movement of the WHDF. This basin rests mainly on hanging wall blocks of the WHDF. The Barstow Formation is itself folded, 
but this disruption is probably a result of later strike-slip faulting [Dibblee, 1968, p. 46]. Dokka et al. [1988] and Dokka [1989] suggested that Tertiary strata in the Mud Hills were deposited in a postdetachment half graben along a large NE dipping high-angle normal fault. They inferred this fault to be concealed by alluvium along the northeast side of the Mitchel Range and Waterman Hills. Stratigraphic relations argue against this interpretation. Pickhandle strata in the Mud Hills are compositionally similar to strata in the Waterman Hills in that both sequences lack clasts derived from preTertiary rocks of the Waterman Hills or Mitchel Range. This is difficult to explain if the section in the Mud Hills was deposited along a fault that uplifted the Waterman Hills basement by $1 \mathrm{~km}$ or more. In addition, the presence of Pickhandle strata in the Waterman Hills argues against Pickhandle Formation being deposited in a half-graben basin entirely north $(5 \mathrm{~km})$ of the Waterman Hills.

We interpret Pickhandle rocks in both the Waterman Hills and Mud Hills to have been deposited during development of the WHDF, many kilometers to the southwest of their present location. The Mud Hills basement and its cover of Pickhandle strata later were transported along the WHDF across the Waterman Hills-Mitchel Range core complex to their present position. The concealed contact between Miocene strata in the Mud Hills and pre-Tertiary basement is interpreted to be the WHDF itself, arched over the northern Waterman Hills and dipping under the Mud Hills (Figures 7 and 8) [Glazner et al., 1989].
Conglomerate and breccia sheets in unit Ts contain clasts that do not match exposed basement in the Waterman Hills or other nearby ranges. Exotic clast lithologies include biotite-rich diorite, black hornfels (metachert?), banded metasedimentary calc-silicate rocks, porphyritic granitoids with K-feldspar phenocrysts up to $3 \mathrm{~cm}$ across, coarse-grained white marble, pelitic gneiss, and gneissic granitoids. Clasts of biotite-rich diorite commonly exceed $1 \mathrm{~m}$ in diameter, and brecciated boulders up to $2.5 \mathrm{~m}$ in diameter are locally present. Mylonitic clasts are absent in the section, suggesting that the ductile shear zone in the Waterman Hills had not yet been exposed during deposition of these units.

In an effort to identify a source for the exotic clasts, we examined all of the ranges surrounding the Waterman Hills, including the Mitchel Range, the Hinkley Hills, Mount General, the Newberry Mountains, Iron Mountain, Fremont Peak, The Buttes, the Calico Mountains, the Lane Mountain area, the Mud Hills, the Gravel Hills, and Alvord Mountain (Figures 1 and 3). More than one area provides a match for a limited subset of clast lithologies. For example, possible matches for the marble and pelitic gneiss clasts, and no others, are present at Iron Mountain. Near Lane Mountain we found reasonable matches for only the hornfels, calc-silicates, marble, and gneiss. The best match of the complete clast assemblage occurs on the western flank of Alvord Mountain [Byers, 1960], where biotite-rich diorite, porphyritic granitoids, coarsegrained white marble, calc-silicate rocks, pelitic gneiss,

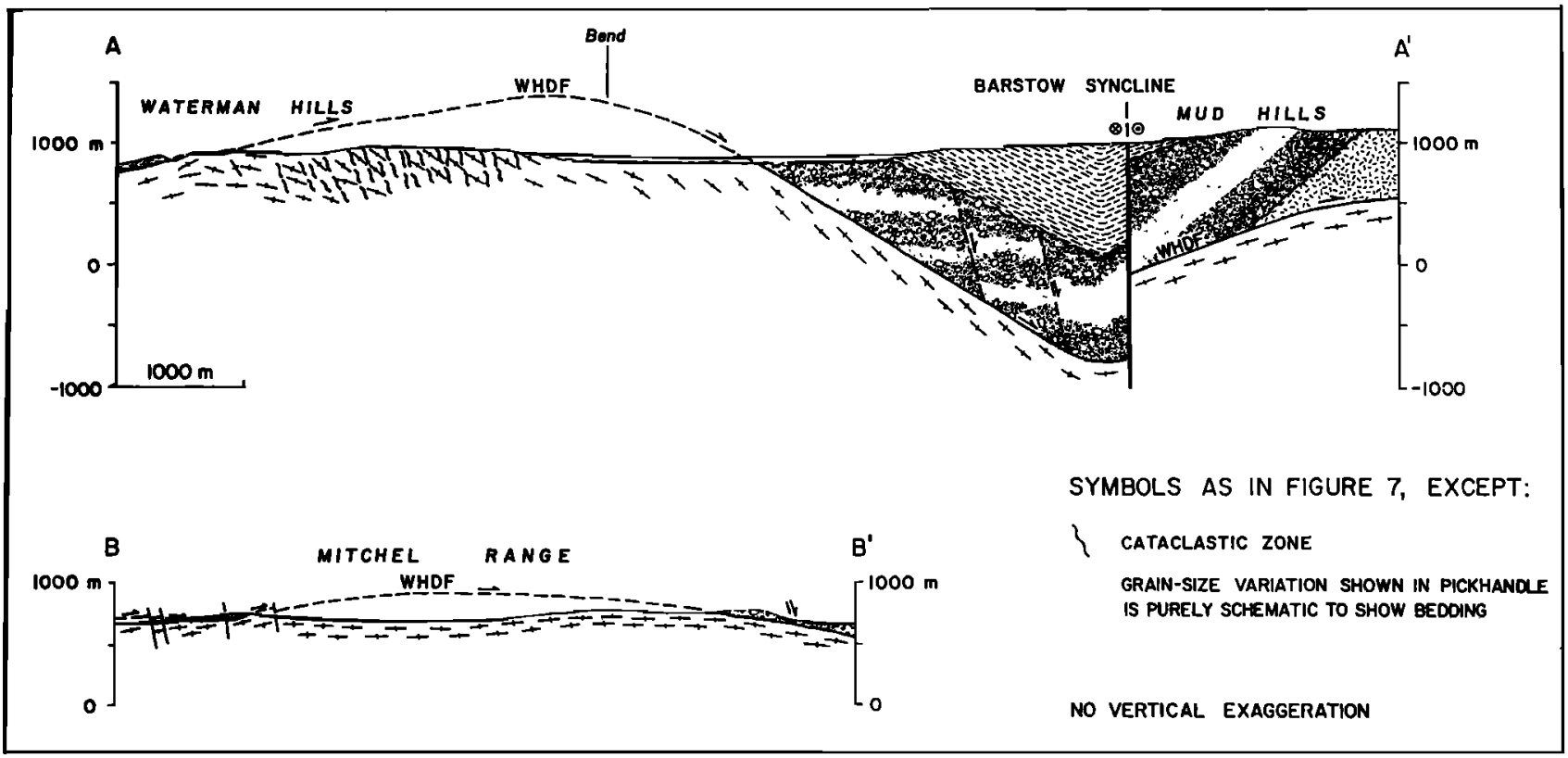

Fig. 8. Cross sections of the WHDF; see Figure 7 for locations. The northern half of cross section A is modified from Dibblee [1968, Plate 3, cross section C-C']. Cross section A-A' illustrates our interpretation that the WHDF is arched over the Waterman Hills and dips under the Mud Hills (see text for discussion). This geometry is corroborated by the arched shape of the WHDF $3 \mathrm{~km}$ along strike in cross section B-B'. Fabric elements shown in the Waterman Hills and Mitchel Range basements are projected from surface mapping but are schematic under the Barstow syncline. The WHDF is shown folded by the Barstow syncline based on the observation that the posttectonic Barstow Formation is folded. 
and gneissic granitoids all are present. The Alvord Mountain area is the only location that contains sources for all of the different types of exotic clasts in the Waterman Hills.

The western flank of Alvord Mountain currently lies

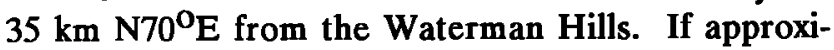
mately $10-15 \mathrm{~km}$ of movement on intervening right-slip faults is removed [Dokka, 1983], Alvord Mountain restores to a position approximately $35 \mathrm{~km} \mathrm{N40} 0^{\circ} \mathrm{E}$ of the Waterman Hills. The direction from the Waterman Hills to the restored position of Alvord Mountain is essentially the same as the lineation direction in the lower plate of the WHDF and presumably the movement direction of hanging-wall fault blocks.

Deriving the coarse basement clasts in the Waterman Hills section from such a distance appears problematic. It is unlikely that the very coarse breccia sheets traveled $35 \mathrm{~km}$. Therefore, either the Alvord Mountain area was closer to the Waterman Hills during Pickhandle deposition and was later shifted away from the Waterman Hills by northeast directed extension or the exotic clasts were derived not from Alvord Mountain but from a nearer area that is now either buried or completely eroded away. We prefer the former hypothesis, because translation of the Alvord Mountain terrane after deposition of the Waterman Hills Tertiary section is consistent with other evidence of continued postdepositional extension (see below).

We therefore interpret the Pickhandle Formation to record synkinematic deposition in a basin formed by slip along the WHDF. Detritus was shed from highlands created in the hanging wall of the detachment and from elevated hanging-wall blocks. The Alvord Mountain area would be one such hanging-wall block. This relation is analogous to modern deposition in Death Valley, where major alluvial fans transport sediment into the basin from the Panamint Range hanging-wall block.

\section{Structure of Upper Plate}

The upper plate of the WHDF is preserved in the Waterman Hills and Mitchel Range as thin, sparse, structurally complex klippen (Figures 2, 7, and 8). Consequently, our knowledge of upper-plate deformation is limited. Myriad centimeter-scale normal faults disrupt and extend bedding in stratified outcrops [Glazner et al., 1988a, Figure 14]. A few map-scale faults are shown in the upper plate in Figure 2, but many more smaller-scale ones exist. Laterally discontinuous sedimentary units and occurrences of similar strata at different stratigraphic levels make recognition of faults difficult.

The largest klippe comprises the central part of the Waterman Hills (Figure 2). The primary structure of the stratified rocks in this klippe is a southwest plunging noncylindrical syncline. The limbs of the syncline have steep and locally overturned dips, the north limb striking west and the south limb striking north. Bedding in the hinge zone dips moderately to the southwest. The average bedding attitude is broadly compatible with synthetic stratal rotation above northeast dipping normal faults, but the geometry implies a more complex three-dimensional deformation history than simple northeastsouthwest stretching. Some of the folding may be related to Late Cenozoic strike-slip faulting along the Harper Lake fault-Gravel Hills fault. For example, fold axes in the Waterman Gneiss in the Hinkley Hills and Mitchel Range are bent in a right-lateral sense adjacent to the Harper Lake fault [Dibblee, 1960, 1970].

Rhyolite plugs (Tr) make up about half of the klippe in the Waterman Hills. The plugs cut across the syncline defined by their wall rocks, indicating that they were emplaced after most, if not all, of the folding of the stratified sequence occurred. Both the plugs and a zone of upper plate potassium metasomatism are truncated against the WHDF, indicating that significant displacement along the WHDF occurred after the plugs were emplaced. This demonstrates important post-Pickhandle extension. Such extension may be responsible for displacement of Alvord Mountain northeastward from closer to the Waterman Hills and Mitchel Range.

A prominent northwest striking high-angle fault offsets the trace of the WHDF on the south side of the klippe with right-lateral separation (Figure 2). In plan view this fault separates steeply dipping lithologic units in the Waterman Gneiss (not shown in Figure 2) by the same amount that it separates the gently dipping WHDF. This requires net slip across the high-angle fault to be largely right-lateral. The fault is probably related to the late Cenozoic right-slip Harper Lake fault that bounds the Waterman Hills on the southwest (Figure 7).

Two small klippen at the northwest end of the Mitchel Range are composed almost entirely of brecciated, altered, structureless rhyolite. However, a small enclave of volcanogenic sandstone at the east end of the larger of these klippen dips about $60^{\circ} \mathrm{NE}$ and is overturned, based on small-scale cross stratification. Moderately extensive upper plate outcrops are located along the northern edge of the Mitchel Range (Figure 2). These comprise a faulted suite of Pickhandle strata (Ts) intruded by rhyolite. Hydrothermal silicification and tourmalinization are commonly intense in this area, rendering protolith identification difficult in some instances. Bedding attitudes and facing directions are inconsistent and indicate both synthetic and antithetic rotations.

\section{Discussion}

\section{Regional Distribution of Upper and Lower Plates}

In the Waterman Hills and Mitchel Range the WHDF juxtaposes Tertiary synextensional strata of the Pickhandle Formation against ductilely deformed, tectonically denuded basement rocks. The top-tonortheast shear sense in the lower plate indicates that 
upper plate basement underlies ranges to the northeast, i.e., the Mud Hills, Lane Mountain, and Alvord Mountain areas. Conversely, this suggests that the WHDF projects above ranges to the southwest (Hinkley Hills, Iron Mountain), which contain pre-Tertiary rock suites similar to the Waterman Hills and Mitchel Range.

In addition to abundant Mesozoic plutonic rocks, upper plate ranges contain a distinctive assemblage of Paleozoic eugeoclinal rocks, mainly at greenschist metamorphic grade. The footwall ranges also contain abundant and similar Mesozoic igneous rocks, but metasedimentary strata represent miogeoclinal to cratonal Paleozoic rocks [Kiser, 1981]. These miogeoclinal to cratonal rocks underwent amphibolite facies metamorphism before being overprinted by the lower greenschist facies mylonitic fabric related to extension. The later mylonitic fabric is most pronounced in exposures in the Waterman Hills, Hinkley Hills, and Mitchel Range, whereas the ranges farther to the west apparently exhibit only the amphibolite grade metamorphism. Therefore the WHDF separates terranes that contain similar Mesozoic igneous assemblages and different Paleozoic rocks and metamorphic facies.

A small exposure of unmetamorphosed fossiliferous upper Paleozoic rocks in the Hinkley Hills may also lie in the upper plate of the WHDF. These rocks rest in low-angle fault contact with the Waterman gneiss and were interpreted to represent the miogeoclinal Bird Spring Formation [Kiser, 1981]. Because of the very limited exposure of these rocks, however, the assignment to either miogeoclinal or eugeoclinal facies is uncertain. In addition, unmetamorphosed Paleozoic rocks are unknown in any of the surrounding ranges. This small exposure, therefore, may provide important clues to preextensional configuration of this area once it and surrounding areas are studied in more detail. The presence of these rocks does not affect the overall distribution of eugeoclinal rocks in the upper plate and miogeoclinal rocks in the lower plate of the WHDF.

\section{Slip Across the Waterman Hills Detachment Fault}

Because the Paleozoic rocks of upper and lower plates are completely different, they cannot be used to constrain the amount of slip on the detachment. However, Mesozoic intrusive rocks may provide such a constraint. Distinctive poikilitic hornblende gabbro bodies in the Mud Hills, in the Goldstone area, and at Iron Mountain (Figures 3 and 9) consist of subequal amounts of hornblende (variably altered) and plagioclase, with variable proportions of hypersthene, augite, magnetite, and sphene. The northeastern occurrences of these intrusions, in the Mud Hills and Goldstone areas, lie in the upper plate of the detachment. Exposures at Iron Mountain are inferred to be in the lower plate because (1) they are located southwest of known lower plate outcrops of the northeast rooting detachment; (2) metasedimentary rocks in this area appear to be

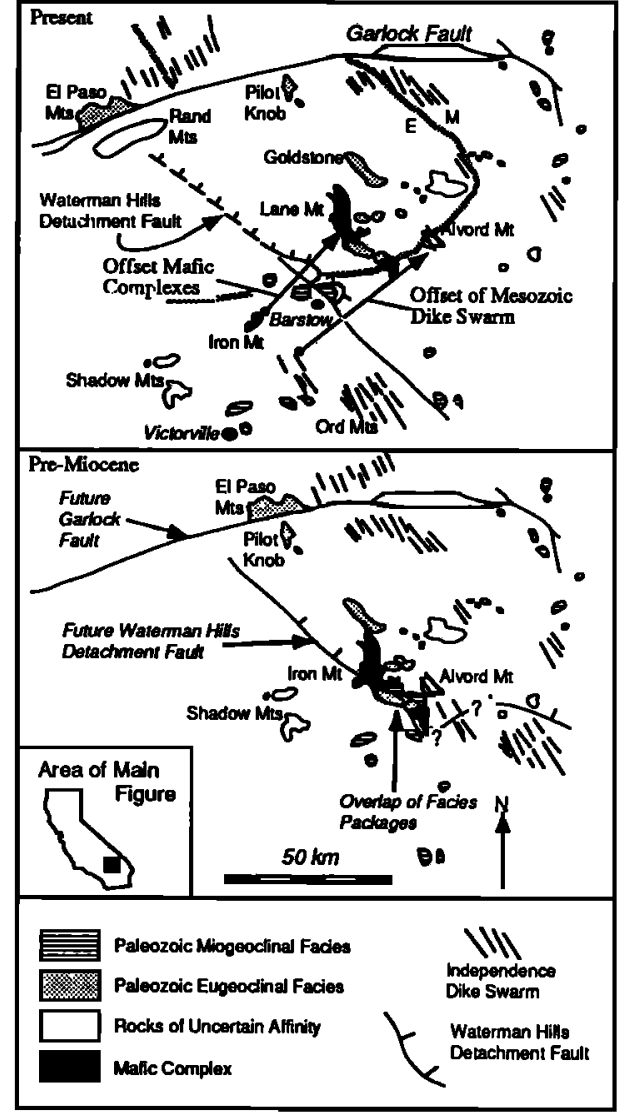

Fig. 9. (Top) Present outcrop distribution of eugeoclinal and miogeoclinal Paleozoic facies (boundary approximately located with heavy stippled line, $\mathbf{E}$ on eugeoclinal and $\mathbf{M}$ on miogeoclinal sides, respectively), locations of mafic complexes (poikilitic gabbro bodies), and regional distribution of upper and lower plates of the Waterman Hills detachment. (Bottom) Restored positions of Paleozoic and Mesozoic rocks prior to motion on Waterman Hills detachment. Note overlap of eugeoclinal and miogeoclinal facies rocks in the central Mojave Desert. Southern continuation of the WHDF is shown schematically as an accommodation zone between the Newberry Mountains and the Mitchel Range.

miogeoclinal in character, similar to known lower plate Paleozoic strata, and are metamorphosed at amphibolite grade; and (3) only unmetamorphosed Tertiary and Paleozoic rocks are present in the upper plate of the detachment southwest of the Mud Hills. Restoration of the Goldstone and Mud Hills gabbro bodies to a position structurally above the gabbro in the Iron Mountain suggests $30-50 \mathrm{~km}$ of top-to-northeast displacement on the WHDF (with later strike-slip faults restored; arrows on Figure 9).

\section{Regional Extent of the Waterman Hills Detachment Fault}

The areal extent of the WHDF remains uncertain, but some constraints can be identified. The fault is difficult to trace to the northwest because volcanic rocks in the northern Mojave Desert, which largely postdate movement on the WHDF [Glazner, 1989], obscure the early Miocene geology and because much of the area lies unexamined within the China Lake Naval Weapons 
Center. Eugeoclinal rocks containing west-southwest vergent structures occur in a continuous northwest trending belt running from the Lane Mountain area northwest to Pilot Knob Valley (Figures 3 and 9), and beyond to the El Paso Mountains when offset across the Garlock Fault is restored [Carr et al., 1984]. The continuity of this belt implies that all of these areas rest in the hanging wall of the WHDF. The footwall of Mesozoic plutons and Waterman Gneiss may also be more or less continuous from the Hinkley Hills to the northwest through the Fremont Peak area to the Johannesburg Gneiss in the Rand Mountains (Figures 1 and 9), but the details of this terrane are known only in reconnaissance. These relations suggest that the WHDF may continue uninterrupted northwestward, east of Fremont Peak and the Rand Mountains.

It is possible that the WHDF may continue northwestward as the proposed Harper Lake detachment of Dokka et al. [1988] and Dokka [1989]. However, we have examined the outcrops that Dokka et al. [1988, Figure 11 and stop 5] used to define this structure. The detachment is identified as the contact between quartz monzonite (presumed upper plate) and mafic to intermediate orthogneiss (presumed lower plate; Waterman Gneiss of Dibblee [1968]). At stop 5 of Dokka et al. [1988] the contact is a moderately dipping cataclastic fault of unknown magnitude that lacks associated mylonite. The other good, and more extensive, exposure of the contact is located $2 \mathrm{~km}$ to the northwest of stop 5 . At this locality the contact of the gneiss with the quartz monzonite is highly irregular in three dimensions, dikes of quartz monzonite cut the mafic orthogneiss, and a roughly east striking vertical crystalloblastic foliation (quite unlike the Tertiary mylonitic fabric of the WHDF) passes through the contact. These observations lead us to suspect that the "Harper Lake detachment" is a locally faulted intrusive contact of probable Mesozoic age and not a likely continuation of the WHDF.

The southern continuation of the detachment is equally obscure. Dokka [1986] inferred a northeast trending right-slip fault, the Kane Springs fault, in the Newberry Mountains (Figure 3), and correlated it eastward with the Silver Bell fault of Sanner [1985]. Dokka interpreted the Kane Springs fault to separate extended rocks of the Newberry Mountains from presumably unextended pre-Tertiary rocks in the Rodman Mountains. This implies that the Kane Springs and Silver Bell faults form the southern boundary of the WHDF. However, Sanner [1985] showed that syndepositional right-slip displacement on the Silver Bell fault is limited to at most $5 \mathrm{~km}$. Continuity of lithologic units across Kane Wash [Dibblee, 1964, 1966] also suggests a similarly small displacement of units in that area. Thus the Kane Springs fault probably did not accommodate the large magnitude of slip we infer across the WHDF. This raises two possibilities: either there is a major concealed accommodation zone between the
Mitchel Range and the Newberry Mountains (Figures 1 and 3) [Dokka, 1989], or pre-Tertiary rocks south of the Newberry Mountains are also extended.

\section{Implications for Mesozoic and Paleozoic Paleogeography}

Large displacement across the Waterman Hills detachment fault has important implications for the Mesozoic and Paleozoic development of the region because the fault carries eugeoclinal Paleozoic rocks in its hanging wall and has miogeoclinal to cratonal Paleozoic rocks in its footwall. Restoration of the WHDF places eugeoclinal rocks structurally above miogeoclinal-cratonal rocks, and we interpret this to mean that eugeoclinal rocks previously were thrust over the miogeoclinal strata [Glazner et al., 1989]. Contrasts in metamorphic facies also supports this stacking. However, Burchfiel and Davis [1981] and Walker [1988] interpreted the eugeoclinal rocks in the northwestern Mojave Desert to have been emplaced in late Paleozoic time by strike-slip faulting that offset them from the Antler belt in eastern California. This interpretation was based on the lack of intervening outer miogeoclinal facies rocks and Antler clastic sediments between the exposures of the miogeoclinal and eugeoclinal rocks (features always seen in the rest of the Cordillera) and the presence of upper Paleozoic basinal rocks in eastern California and the northeastern Mojave Desert. We accept this interpretation for primary juxtaposition of miogeoclinal-cratonal with eugeoclinal rocks in the Mojave Desert, but the strike-slip boundary was presumably modified by Mesozoic crustal shortening to create the vertical stacking indicated by our reconstructions.

Reconstruction of the WHDF also affects the distribution of Mesozoic batholithic rocks, including the Mesozoic dike swarm. The western margin of the dike swarm in eastern California continues into the northern Mojave Desert in the vicinity of Alvord Mountain [Smith, 1962; Chen and Moore, 1979; Miller and Sutter, 1982]. From here the dikes extend westward to the Ord Mountain area (Figures 1 and 9). Removing displacement on the WHDF aligns the dike swarm in the Alvord Mountain area with similar dikes in the Ord Mountains (Figure 9). This indicates that the amount of slip inferred from the possible offset of gabbroic bodies is plausible, because it also restores the dikes to a continuous trend. This further implies that no major fault older than the WHDF and younger than the Jurassic dikes, e.g., the Mojave-Sonora megashear [Silver and Anderson, 1974], passes through the Mojave Desert in areas east of Victorville.

This proposed restoration implies that contrasting Paleozoic facies were vertically stacked prior to emplacement of the Independence Dike swarm in the Late Jurassic. The presence of Lower Triassic marine rocks overlain paraconformably by Lower Jurassic vol- 
canic rocks [Grose, 1959; Miller, 1981; Marzolf, 1983; Busby-Spera et al., 1987] across the Mojave Desert places an older bound on thrusting, so that this major compressional event must have occurred roughly during late Early to Middle Jurassic time.

Acknowledgments. We would like to thank K. A. Howard, R. A. Schweickert, and D. M. Miller for helpful reviews of this paper. Finuncial support was provided by NSF grant EAR-8816628 and a if :ll Faculty Fellowship to Walker.

\section{REFERENCES}

Bartley, J. M., and A. F. Glazner, Tertiary deformation beneath the Waterman detachment, central Mojave Desert, California, Geol. Soc. Am. Abstr. Programs., 19, 582, 1987.

Bartley, J. M., Fletcher, J. M., and A. F. Glazner, Tertiary extension and shortening of lower-plate rocks in the central Mojave metamorphic core complex, southern California, Tectonics, in press, 1989.

Bennett, V. C., and D. J. DePaolo, Proterozoic crustal history of the western United States as determined by neodymium isotopic mapping, Geol. Soc. Am. Bull., 99, 674-685, 1987.

Bowen, O. E., Geology and mineral deposits of the Barstow Quadrangle, San Bernardino County, California, Bull. 165, 208 pp., Div. of Mines, Calif. Dep. of Nat. Resour., Sacramento, 1954.

Burchfiel, B. C., and G. A. Davis, Mojave Desert and environs, in The Geotectonic Development of California, edited by W. G. Ernst, pp. 217-252, Prentice-Hall, Englewood Cliffs, N. J., 1981.

Busby-Spera, C. J., J. M. Mattinson, and N. R Riggs, Lower Mesozoic extensional continental arc, Arizona and California: A depocenter for craton-derived quartz arenites, Geol. Soc. Am. Abstr. Programs, 19, 607, 1987.

Byers, F. M., Jr., Geology of the Alvord Mountain quadrangle, San Bernardino County, California, U.S. Geol. Sunv, Bull. 1089-A, 71 Pp., 1960.

Carr, M. D., R. L. Christiansen, and F. G. Poole, Pre-Cenozoic geology of the El Paso Mountains, southwestern Great Basin, California - A summary, in Western Geological Excursions, vol. 4, edited by J. Lintz, Jr., pp. 84-93, Department of Geological Sciences, Mackay School of Mines, Reno, Nev., 1984.

Chen, J. H., and J. G. Moore, Late Jurassic Independence dike swarm in eastern California, Geology, 7, 129-133, 1979.

Davis, G. A., and G. S. Lister, Detachment faulting in continental extension; perspectives from the southwestern U.S. Cordillera, Spec. Pap. Geol. Soc. Am., 218, 133-159, 1988.

Davis, G. A., J. L. Anderson, E. G. Frost, and T. J. Shackelford, Mylonitization and detachment faulting in the Whipple-BuckskinRawhide Mountains terrane, southeastern California and western Arizona, Mem. Geol. Soc. Am., 153, 79-129, 1980.

Davis, G. H., and P. J. Coney, Geological development of the Cordilleran metamorphic core complexes, Geology, 7, 120-124, 1979.

Dibblee, T. W., Jr., Geologic map of the Barstow quadrangle, San Bernardino County, California, scale 1:62,500, U.S. Geol. Suw. Map, MF-233, 1960.

Dibblee, T. W., Jr., Geologic map of the Rodman Mountains quadrangle, San Bemardino County, California, scale 1:62,500, U.S. Geol. Surv. Map, I-430, 1964.

Dibblee, T. W., Jr., Geologic map of the Newberry quadrangle, San Bernardino County, California, scale 1:62,500, U.S. Geol. Surv. Map, $1-461,1966$.

Dibblee, T. W., Jr., Geology of the Fremont Peak and Opal Mountain quadrangles, Califomia, Bull. Calif. Div. Mines and Geol., 188, 64 pp., 1968.

Dibblee, T. W., Jr., Geologic map of the Daggett quadrangle, San Bemardino County, California, scale 1:62,500, U.S. Geol. Surv. Map, I-592, 1970.

Dokka, R. K. Displacement on late Cenozoic strike-slip faults of the central Mojave Desert, California, Geology, 11, 305-308, 1983.

Dokka, R. K., Pattems and modes of early Miocene crustal extension, central Mojave Desert, California, Spec. Pap. Geol. Soc. Am., 208, $75-95,1986$

Dokka, R. K., The Mojave extensional belt of southem California, Tectonics, 8, 363-390, 1989.
Dokka, R. K, and A. K. Baksi, Thermochronology of detachment faults of the Mojave extensional belt, California: A progress report: Geol. Soc. Am. Abstr. Programs, 20, A16, 1988.

Dokka, R. K, and A. F. Glazner, Aspects of Early Miocene extension of the central Mojave Desert, Field Trip Guidebook, pp. 31-46, Cordilleran Sect., Geol. Soc. of Am., Fresno, Calif., 1982.

Dokka, R. K., and M. O. Woodburne, Mid-Tertiary extensional tectonies and sedimentation, central Mojave Desert, California, La. State Univ. Publ. Geol. Geophys. Tectonics Sediment., 1, 55 pp., 1986.

Dokka R K, M. McCurry, M. O. Woodburne, E. G. Frost, and D. A. Okaya, A field guide to the Cenozoic structure of the Mojave Desert, in This Extended Land - Geological Journeys in the Southern Basin and Range, Spec. Publ. 2, edited by D. L. Weide and M. L. Faber, pp. 21-49, University of Nevada-Las Vegas, 1988.

Glazner, A. F., Stratigraphy, structure, and potassic alteration of Miocene volcanic rocks in the Sleeping Beauty area, central Mojave Desert, California, Geol. Soc. Am. Bull., 100, 424-435, 1988.

Glazner, A. F., Recycling of continental crust in Miocene volcanic rocks from the Mojave block, southern California, Mem. Geol. Soc. Am., 174, in press, 1989.

Glazner A. F., J. M. Bartley, and J. D. Walker, Geology of the Waterman Hills detachment fault, central Mojave Desert, California, in This Extended Land - Geological Journeys in the Southern Basin and Range, Spec. Publ. 2, edited by D. L. Weide and M. L. Faber, pp. 225-237, University of Nevada-Las Vegas, $1988 a$.

Glazner, A. F., J. D. Walker, J. M. Bartley, S. B. and Dent, Distribution and relations of Precambrian and Paleozoic rocks in the central Mojave Desert, California, Geol. Soc. Am. Abstr. Programs, 20, 163, $1988 b$.

Glazner A. F., J. M. Bartley, and J. D. Walker, Magnitude and significance of Miocene crustal extension in the central Mojave Desert, California, Geology, 17, 50-54, 1989.

Grose, L. T., Structure and petrology of the northeast part of the Soda Mountains, San Bernardino County, California, Geol. Soc. Am. Bull., 70, 1509-1548, 1959.

Hileman, G. E., C. Miller, and M. Knoll, Mid-Tertiary structural evolution of the Old Woman Mountains area: Implications for crustal extension across southeastern California, J. Geophys. Res., this issue.

Jennings, C. W., Geologic map of California, scale 1:750,000, Calif. Div. of Mines and Geol., Sacramento, 1977.

Kiser, N. L., Stratigraphy, structure and metamorphism in the Hinkley Hills, Barstow, Califomia, M.S. thesis, 70 pp., Stanford Univ., Stanford, Calif., 1981.

Kistler, R. W. and Z. E. Peterman, Reconstruction of crustal blocks of California on the basis of initial strontium isotopic compositions of Mesozoic plutons, U.S. Geol. Surv. Prof. Pap., 71, 1978.

Kramer, H., and R. D. Allen, Analyses and indices of refraction of tourmaline from fault gouge near Barstow, San Bernardino County, California, Am. Mineral., 39, 1020-1023, 1954.

Krogh, T.E., A low contamination method for hydrothermal decomposition of zircon and extraction of $\mathrm{U}$ and $\mathrm{Pb}$ for isotopic age determinations, Geochim. Cosmochim. Acta, 37, 485-494, 1973.

Krogh, T.E., Improved accuracy of U-Pb zircon ages by the creation of more concordant systems using air abrasion technique, Geochim. Cosmochim. Acta, 46, 637-649, 1982.

Lahren, M. M., and R. A. Schweickert, Proterozoic and Lower Cambrian miogeoclinal rocks of Snow Lake pendant, YosemiteEmigrant Wilderness, Sierra Nevada, Califomia: Evidence for major Early Cretaceous dextral translation, Geology, 17, 156-160, 1989.

Ludwig, K.R., Plotting and regression programs for isotope geochemists, for use with HP 86/87 microcomputers, U.S. Geol. Surv. Open File Rep., 83-849, 102 pp., 1983.

Marzolf, J. E., Early Mesozoic colian transition from cratonal margin to orogenic volcanic arc, in Evolution of Early Mesozoic Tectonostratigraphic Environments-Southwestern Colorado Plateau to Southern Inyo Mountains, Spec. Stud. 60, Guideb. Part 2, pp. 3946, Utah Geological and Mineral Survey, edited by J. E. Marzolf and G. C. Dunne, Salt Lake City, 1983.

McCulloh, T. H., Geology of the southern half of the Lane Mountain quadrangle, California, Ph.D. dissertation, 180 pp., Univ. of Calif., Los Angeles, 1952.

McFadden, B. J., M. O. Woodburne, and N. J. Opdyke, 
Paleomagnetism and negligible tectonic rotation of Miocene Hector and Barstow formations, Mojave Desert, Califormia, Geol. Soc. Am. Abstr. Programs, 20, 176-177, 1988.

Miller, E. L., Geology of the Victorville region, California, Geol. Soc. Am. Bull., part II, 92, 554-608, 1981.

Miller, E. L., and J. F. Sutter, Structural geology and ${ }^{40} \mathrm{Ar}-{ }^{39} \mathrm{Ar}$ geochronology of the Goldstone-Lane Mountain area, Mojave Desert, California, Geol. Soc. Am. Bull., 93, 1191-1207, 1982.

Parrish, R. R, An improved micro-capsule for zircon dissolution in U-Pb geochronology, Chem. Geol., 66, 99-102, 1987.

Sanner, WJ., Tectonic significance of early Miocene basin fill in the Box Canyon area, Mojave Desert, California, M.S. thesis, 66 pp., Univ. of N. C., Chapel Hill, 1985.

Silver, L. T., and T. H. Anderson, Possible left-lateral early to middle Mesozoic disruption of the southwestern North American craton margin, Geol. Soc. Am. Abstr. Programs, 6, 955-956, 1974.

Smith, G. I., Large lateral displacement on Garlock fault, California, as measured from offset dike swarm, Am. Assoc. Pet. Geol. Bull., 46, 85-104, 1962.

Stacey, J.S., and J. D. Kramers, Approximation of terrestrial lead isotope evolution by a two-stage model, Earh Planet. Sci. Lett., 26, 207-221, 1975.

Steiger, R.H., and E. Jäger, Subcommission on geochronology convention on the use of decay constants in geo- and cosmochronology, Earth Planet. Sci. Lett., 1, 369-371, 1977.

Walker, J. D., Permo-Triassic paleogeography and tectonics of the southwestern United States, Ph.D. dissertation, 236 pp., Mass. Inst. of Technol., Cambridge, 1985.

Walker, J.D., Permian and Triassic rocks of the Mojave Desert and their implications for timing and mechanisms of continental truncation, Tectonics, 7, 685-709, 1988.

Wooden, J. L., D. M. Miller, and K. A. Howard, Early Proterozoic chronology of the eastern Mojave Desert, Geol. Soc. Am. Abstr. Programs, 20, 243, 1988.

J. M. Bartley, Department of Geology and Geophysics, University of Utah, Salt Lake City, UT 84112.

A. F. Glazner, Department of Geology, CB 3315 Mitchell Hall, University of North Carolina, Chapel Hill, NC 27599.

J. D. Walker, Department of Geology, University of Kansas, Lawrence, KS 66045.

(Received January 26, 1989;

revised July 20, 1989,

accepted June $25,1989$. 